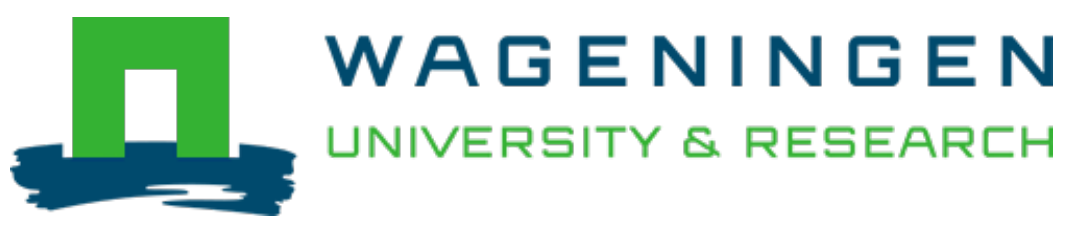

\author{
Moderate pollination limitation in some entomophilous crops of Europe \\ Agriculture, Ecosystems and Environment \\ Holland, John M.; Sutter, Louis; Albrecht, Matthias; Jeanneret, Philippe; Pfister, Sonja C. et al \\ https://doi.org/10.1016/j.agee.2020.107002
}

This publication is made publicly available in the institutional repository of Wageningen University and Research, under the terms of article $25 \mathrm{fa}$ of the Dutch Copyright Act, also known as the Amendment Taverne. This has been done with explicit consent by the author.

Article $25 \mathrm{fa}$ states that the author of a short scientific work funded either wholly or partially by Dutch public funds is entitled to make that work publicly available for no consideration following a reasonable period of time after the work was first published, provided that clear reference is made to the source of the first publication of the work.

This publication is distributed under The Association of Universities in the Netherlands (VSNU) 'Article $25 \mathrm{fa}$ implementation' project. In this project research outputs of researchers employed by Dutch Universities that comply with the legal requirements of Article $25 \mathrm{fa}$ of the Dutch Copyright Act are distributed online and free of cost or other barriers in institutional repositories. Research outputs are distributed six months after their first online publication in the original published version and with proper attribution to the source of the original publication.

You are permitted to download and use the publication for personal purposes. All rights remain with the author(s) and / or copyright owner(s) of this work. Any use of the publication or parts of it other than authorised under article $25 \mathrm{fa}$ of the Dutch Copyright act is prohibited. Wageningen University \& Research and the author(s) of this publication shall not be held responsible or liable for any damages resulting from your (re)use of this publication.

For questions regarding the public availability of this publication please contact openscience.library@wur.nl 


\section{Moderate pollination limitation in some entomophilous crops of Europe}

John M. Holland ${ }^{\mathrm{a}, *}$, Louis Sutter ${ }^{\mathrm{b}}$, Matthias Albrecht ${ }^{\mathrm{b}}$, Philippe Jeanneret ${ }^{\mathrm{b}}$, Sonja C. Pfister ${ }^{\mathrm{c}}$, Jens Schirmel $^{\mathrm{c}}$, Martin H. Entling ${ }^{\mathrm{c}}$, Riina Kaasik ${ }^{\mathrm{d}}$, Gabriella Kovacs ${ }^{\mathrm{d}}$, Eve Veromann ${ }^{\mathrm{d}}$, Agustín M. Bartual ${ }^{\mathrm{e}}$, Simone Marini ${ }^{\mathrm{e}}$, Anna-Camilla Moonen ${ }^{\mathrm{e}}$, Márk Szalai ${ }^{\mathrm{f}}$, Herman Helsen ${ }^{g}$, Karin Winkler ${ }^{g}$, Marjolein E. Lof ${ }^{\mathrm{h}}$, Wopke van der Werf ${ }^{\mathrm{h}}$, Niamh M. McHugh ${ }^{\mathrm{a}}$, Barbara M. Smith ${ }^{\mathrm{a}}$, David W. Wallis ${ }^{\mathrm{i}}$, James E. Cresswell ${ }^{\mathrm{i}}$

\footnotetext{
${ }^{\text {a }}$ Game and Wildlife Conservation Trust, Fordingbridge SP6 1EF, United Kingdom

${ }^{\mathrm{b}}$ Agroecology and Environment, Agroscope, CH-8046 Zurich, Switzerland

${ }^{\mathrm{c}}$ University of Koblenz-Landau, iES Landau, Institute for Environmental Sciences, Fortstr. 7, D-76829 Landau, Germany

${ }^{\mathrm{d}}$ Estonian University of Life Sciences, Kreutzwaldi 1, 51006 Tartu, Estonia

e Institute of Life Sciences, Scuola Superiore Sant'Anna, 56127 Pisa, Italy

${ }^{\mathrm{f}}$ Plant Protection Institute, Szent Istvan University, H-2100 Godollo, Hungary

${ }^{\mathrm{g}}$ Wageningen University \& Research, Wageningen Plant Research, Lingewal 1, 6668LA Randwijk, the Netherlands

${ }^{\mathrm{h}}$ Wageningen University \& Research, Crop Systems Analysis, Droevendaalsesteeg 1, 6708PB Wageningen, The Netherlands

${ }^{\mathrm{i}}$ Biosciences, University of Exeter, Exeter EX4 4PS, United Kingdom
}

A R T I C L E I N F O

\section{Keywords:}

Agroecology

Pollinators

Crop yield

Landscape ecology

Pollination

Entomophilous crops

\begin{abstract}
A B S T R A C T
Pollination services to crops may be worsening because of declines in farmland pollinators, but the consequences for yields have been uncertain. We therefore investigated pollination limitation in four entomophilous crops (oilseed rape, sunflower, pears and pumpkin) by quantifying the difference in harvestable mass between openpollinated and saturation-pollinated (hand-pollinated) flowers. We also examined whether pollination limitation in the four crops was associated with the number of flower visits by insects. Across 105 commercial fields in six European countries, the average decrease in harvestable mass due to pollination limitation was $2.8 \%$ $(\mathrm{SE}=1.15)$. Among crops, the highest decreases were in sunflowers $(8 \%)$ and in one of three oilseed rape production regions (6\%). We observed substantial variation among crops in the numbers of insect visits received by flowers, but it did not significantly correspond with the levels of pollination limitation. Our results suggest that yields in these crops were not severely pollination-limited in the regions studied and that other factors besides visitation by pollinators influenced the degree of pollination limitation.
\end{abstract}

\section{Introduction}

Crops with entomophilous flowers such as oilseeds, squash and orchard fruits are important to food security and the farming economy (Losey and Vaughan, 2006). Entomophilous flowers typically have showy petals and offer nectar and/or pollen to visiting insects, which act as pollinators. Among insects, bees are a principal pollinator of many entomophilous crops and their declines in farmland of north western Europe and eastern North America are a cause of concern (Potts et al., 2016) because crop yields might become threatened by pollination limitation (IPBES, 2016; Dainese et al., 2019). Pollination limitation is widespread among wildflowers (Wolowski et al., 2014), but its levels in many crops have been uncertain (Klein et al., 2007). We therefore conducted pollen supplementation experiments in commercial fields to quantify pollination limitation in some of the main entomophilous crops grown in Europe.

We conducted experiments on four entomophilous crops from three product classes (oilseeds, squash and orchard fruit) in regions of six countries (Estonia, Germany, Italy, the Netherlands, Switzerland, and the United Kingdom). Specifically, we measured pollination limitation and the number of insect visits received by flowers in: oilseed rape, Brassica napus L.; sunflower, Helianthus annuus L.; Hokkaido pumpkin, Cucurbita maxima Duch.; and Conference pear, Pyrus communis L. The objectives of our study were: (1) to determine the levels of pollination limitation in various crops and regions; and (2) to examine the association between the pollination limitation and the number of insect visits received by flowers in crop fields.

\footnotetext{
* Corresponding author.

E-mail address: jholland@gwct.org.uk (J.M. Holland).
} 


\section{Methods}

We studied crops of oilseed rape in Estonia, Switzerland and the United Kingdom, sunflower in Italy, pumpkin in Germany and pear in the Netherlands. In each of these six countries in 2014, we studied 18 fields in a single region with representative commercial practice, field sizes and that ranged from low to high levels of semi-natural habitat for the region (Appendix S1.1). The proportion of the main types of seminatural habitat in a $1 \mathrm{~km}$ radius around each field were mapped (Table S1.1). In each field, we quantified pollination limitation by comparing the harvestable mass of pollen-saturated and open-pollinated flowers. Specifically, we estimated pollen limitation as the proportional decrease in harvestable mass observed in open-pollinated flowers relative to saturation-pollinated flowers:

pollen limitation $=100 \times\left[1-\left(M_{\text {open }} / M_{\text {supplemented }}\right)\right] \%$

Focal flowers were located on plants situated along a transect perpendicular to one of the field's edges and these experimental plants were located on the transect at four well-separated distances (Appendix S1). To minimize the influence of the other field boundaries on transects, the distance between the end of the transects and non-focal field boundaries was at least 1.25 times the length of the transect (Bartual et al., 2018).

In each field of sunflower and oilseed rape, outcross pollen was collected from at least five donor flowers, mixed and applied to receptive stigmas on different plants with a soft brush. In pear, a commercial pollen mix (Wellplus Co., Daejeon, Korea) was used to pollinate flowers. Flowers of oilseed rape and pear were hand-pollinated with a single dose whereas in sunflower the many receptive florets of each capitulum were hand-pollinated over three to five occasions at two-day or three-day intervals. In oilseed rape and sunflower, we quantified harvestable mass by the dry mass of mature seed produced per flower (oilseed rape) or capitulum (sunflower). In pears, we quantified the mass of the fruit produced by each experimental flower at the time appropriate to the commercial harvest. In Hokkaido pumpkin, we estimated harvestable mass by quantifying the pollen that had accumulated on stigmas of focal flowers and transforming to expected fruit mass using an experimentally established pollen-fruit mass relationship (Pfister et al., 2017). Each pumpkin flower bloomed for only a few hours and we collected stigmas in the afternoon from senescent flowers which had opened that morning before counting the pollen in a microscope preparation (Pfister et al., 2017). Pollination limitation of each pumpkin flower was estimated by subtracting the estimated fruit mass from its maximum value, which was determined by saturating pollinations (Pfister et al., 2017). The numbers of replicate flowers (hand-pollinated, open-pollinated) in each of the 18 focal fields were: sunflower $(8,32)$; pear $(5,5)$; pumpkin $(0,32)$; oilseed rape: Estonia $(16,96)$, Switzerland $(8,8)$ and the United Kingdom $(8,8)$. To avoid pseudoreplication, we used the mean level of pollination limitation in each field for statistical analysis.

\subsection{Estimating insect visits per flower}

We quantified pollinator visitation by estimating the overall number of insect visits received by a receptive flower (Cresswell, 2008). In each field, we studied the insects visiting crop flowers, including bees, syrphids and other flies, and lepidopteran species during fine weather in 2014. In oilseed rape at each distance along the transect in each field, we recorded the total number of flowers probed by insects over 10minute intervals in at least two $2 \times 2 \mathrm{~m}$ quadrats and we also estimated the area density of flowers (i.e. flowers per $\mathrm{m}^{2}$ ) for $10 \mathrm{~m}^{2}$. We thereby calculated the expected number of insect visits per receptive flower for each field by assuming that flowers were receptive for $8 \mathrm{~h} \mathrm{~d}^{-1} \times 2.7 \mathrm{~d}$ (Bell and Cresswell, 1998). Observations were made in 18 fields per country either once (United Kingdom: 14th-16th April) or twice
(Estonia: 16th May, 6th June; Switzerland: 22nd-24th April, 5th-6th May). In sunflower (Italy), observations were made over $10 \mathrm{~min}$ in two replicate quadrats each containing four capitula. Observations were made in the 18 fields twice on separate days during peak bloom (capitula having $>30 \%$ of florets open) between 24th June and 16th of July. Based on the observed visit rates, we estimated the expected number of insect visits per receptive flower by assuming that each floret in a capitulum was receptive for $8 \mathrm{~h} \mathrm{~d}^{-1} \times 4 \mathrm{~d}$ (OECD, 2005). In pumpkin, we used video cameras (Sony HDR-CX115E, Sony Corporation, Tokyo, Japan) to record the activity of flower visitors. Each field was sampled at each one time period on three different days in July during the flowering period, once at 7:00, 8:30 and 10:00 am. On each occasion, four 15-minute-long videos, one at each 2, 10, 18 and $26 \mathrm{~m}$ transect position, each surveying a different female pumpkin flower. We calculated mean visit rates for each field and calculated the expected number of visits received by a receptive flower by assuming that it was receptive for $4 \mathrm{~h}$ (Pfister et al., 2017). In pear, we observed clusters of approximately 500 flowers on a single branch and counted the number of insects that visited it during a 10-minute period. In each field (orchard) we conducted four replicate observations on one day between 2nd and 10th of April. The exact number of flowers visited by each insect was not recorded but it never exceeded 10, so we estimated per-flower visitation rates by assuming that insects visited either 10 flowers on the cluster or only a single flower. We thereby calculated the number of visits received by a receptive flower under each scenario (i.e. 'probe-one flower' or 'probe 10 flowers' per cluster) by assuming that the duration of a flower's receptivity was $8 \mathrm{~h} \mathrm{~d}^{-1} \times 6.6 \mathrm{~d}$ (Fig. 1).

\section{Results}

We found a moderate but significant level of pollination limitation across 105 commercial fields that produced data (mean $=2.8 \%$ of harvestable mass in supplemented flowers, $\mathrm{SEM}=1.15$; test $\mathrm{H}_{0}: \mu=0$ using standardized deviate on a normal distribution, $z=2.3, P<0.05$ ). Regionally, we detected pollination limitation in sunflower crops in Italy (c. 8\%) and oilseed rape crops in Switzerland (c. 6\%) (Fig. 2a). Western honey bees (Apis mellifera L.), thereafter honey bees, or flies were the dominant flower visitors in all regions (Appendix S2) and the number of insect visits received by flowers varied over ten thousandfold among crops and regions (Fig. 2b). We estimate that sunflower capitula and pumpkin flowers each received more than 100 insect visits (principally bumblebees Bombus spp. and honey bees) during their receptive phase (Fig. 2b). By contrast, in oilseed rape it appears that less than $10 \%$ of flowers received even a single insect visit (Fig. 2b). The variation in insect visitation did not correspond with the levels of pollination limitation (Fig. 2a).

\section{Discussion}

Our results show that the harvestable mass of individual flowers in crop fields was moderately depressed by pollen limitation (mean decrease $=2.8 \%$ ). This finding is probably conservative because pollen supplementation overestimates pollination limitation if plants divert limited resources to well-pollinated flowers (Knight et al., 2006), but resource-limitation seems unlikely in well-fertilized crop fields. Therefore, our assays appear likely to have quantified pollination limitation among the flowers generally and hence indicate potential impacts on overall crop yields. If so, our findings suggest that the crop pollination systems that we studied were underperforming only slightly despite recent bee declines in some European countries (IPBES, 2016).

\subsection{The influence of crop-specific factors on pollination}

Among the focal crops, levels of pollination limitation were unrelated to the intensity of flower visitation by insects, which suggests the influence of crop-specific factors such as the pollination efficacy of 

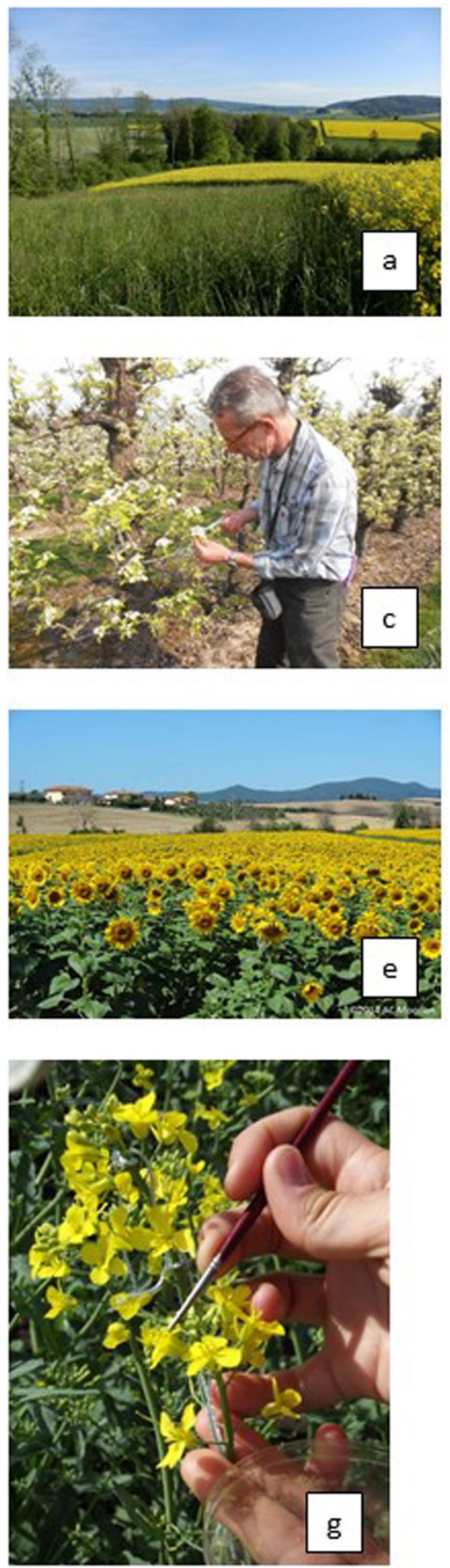
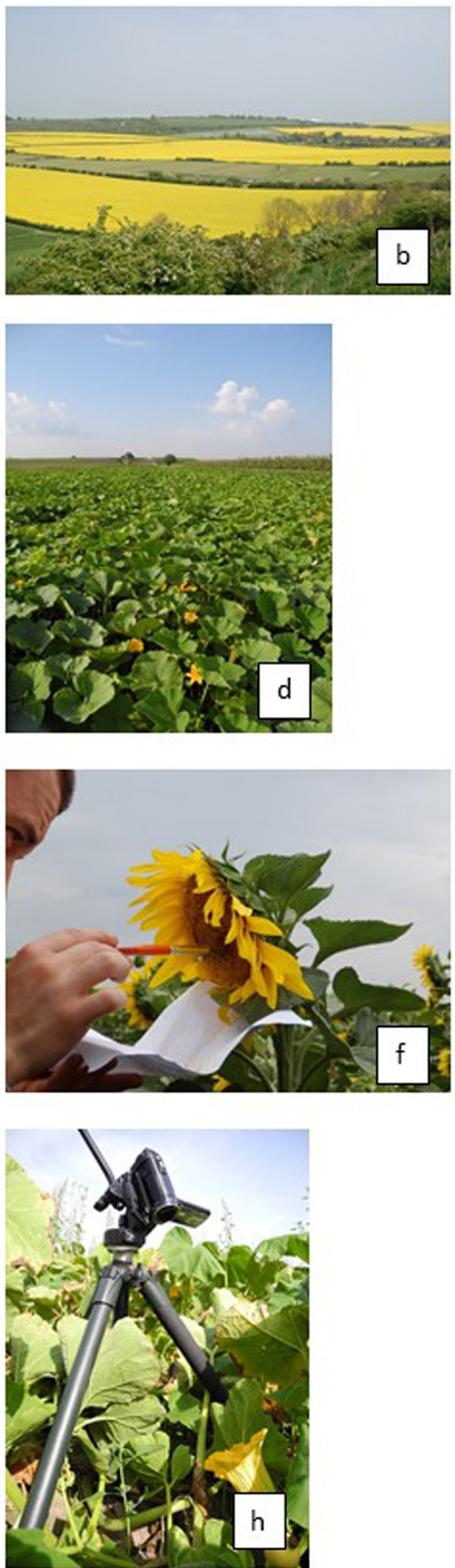

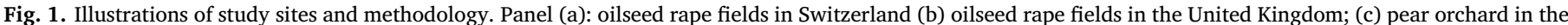

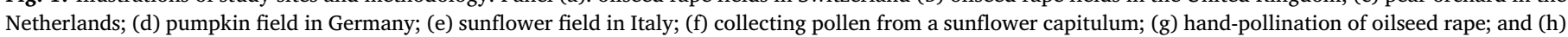
recording insect visits to pumpkin flowers with a video camera.

the single pollinating species. We therefore discuss each crop separately below.

\subsubsection{Sunflower}

Sunflower fields were intensively visited by honey bees (a capitulum apparently received over 100 visits each day, on average), but the crop did not achieve full seed set. Commercial cultivars of sunflower often have a high level of pollinator-dependence (Bartual et al., 2018), but we speculate that pollination by honey bees was incomplete despite their high rate of flower visitation because either individual bees probed only 


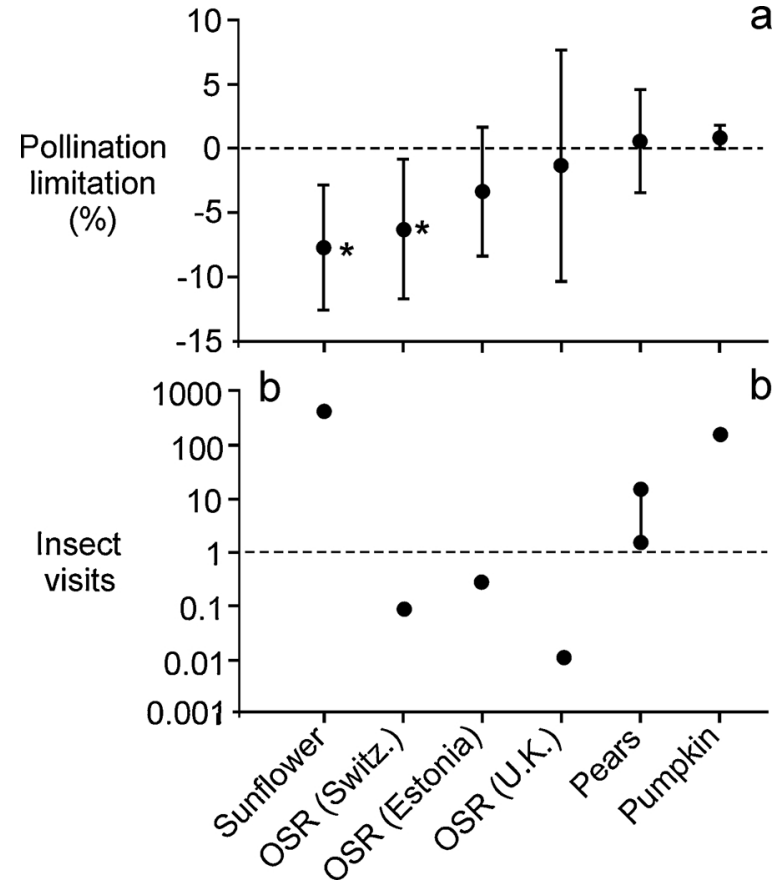

Fig. 2. Pollination limitation (a) and rates of visits to flowers by insects (b) in bee-attractive crops in six European countries. Key to countries and crops:sunflower (Italy); pumpkin (Germany); pears (Netherlands); OSR = oilseed rape (Estonia, Switzerland, United Kingdom). In panel (a) 'pollination limitation (\%)' quantifies the mean difference in yield between open-pollinated and hand-pollinated flowers as a proportion of the yield of hand-pollinated flowers (error bars indicate 1.96 SE). In panel (b) 'insect visits' quantifies the expected number of times that a receptive flower is visited by an insect (for sunflower, the rate quantifies the estimated number of times a receptive floret on the capitulum is visited). For insect visits to pears in the Netherlands only, the joined symbols indicate the upper and lower estimates of the rate. Otherwise, symbols obscure confidence intervals in all cases.

a minority of receptive florets while visiting each inflorescence or their contacts with the sexual parts of the florets were not fully effective.

\subsubsection{Oilseed rape}

We found little pollination limitation in winter-sown oilseed rape despite low levels of insect visitation to flowers. Likewise, in field trials in the UK there was no effect on yield of pollinator exclusion (Garratt et al., 2018). In contrast, insect pollination in winter-sown oilseed rape in France contributed about $30 \%$ to crop yields, determined using pollinator exclusion, potentially because the area had a rich wild bee community (Perrot et al., 2018). Pollinators are normally scarce in the spring-flowering oilseed rape fields of northern Europe where they appear to pollinate no more than two thirds of the flowers, on average (Hoyle et al., 2007; Appendix S3) and was $<10 \%$ in this study. Instead, pollination occurs through flower-to-flower collisions among windblown plants (Hayter and Cresswell, 2006). The regional differences in pollination limitation of oilseed rape may have originated from the differential efficacy of this wind-facilitated pollination, which could be due to variation among local plant varieties (stem flexibility) (Hudewenz et al., 2014), sowing regimes (plant density) or weather (wind speeds) that affected the intensity of wind-sway by plants in the crops. In spring-sown oilseed rape, which blooms in summer, rates of flower visitation by insects are substantially higher than in winter-sown fields (Hayter and Cresswell, 2006). Spring-sown crop varieties also show substantive levels of pollinator dependence (e.g. Lindström et al., 2016).

\subsubsection{Pears}

We found that Dutch pear orchards varied in the level of pollination limitation, but with no overall deficit in the region on average, perhaps because yields were buffered against low numbers of pollinator visits by the capacity of pear to produce fruit by spontaneous parthenocarpy (Quinet and Jacquemart, 2015).

\subsubsection{Pumpkin}

We found no evidence of pollination limitation in German pumpkin fields because the intense activities of honey bees and bumble bees saturated the pollen requirements of flowers (Pfister et al., 2017, 2018).

\subsection{Strategies for sustaining and enhancing pollination}

The female pumpkin flowers in the fields that we studied were saturated by pollen deliveries made principally by honey bees and bumble bees, which are effective pollinators of pumpkin. Pollination services to these pumpkin fields can be sustained by assuring the future abundance of bees. The sunflowers in the fields that we studied were visited intensively by honey bees, but nevertheless seed set was pollination-limited. The basis for the pollination limitation is unclear, but potentially it could be remedied either by increasing the abundance of the most effective wild insect pollinators (Blaauw and Isaacs, 2014; Sutter et al., 2018) or by reducing the pollinator-dependence of the crop, which might involve using varieties with higher levels of autonomous self-pollination. In the pear orchards that we studied, insects apparently visited flowers at rather marginal rates and fruit mass was pollination-limited in some orchards, which suggests that some growers may benefit from boosting pollinator abundance. In the studied oilseed rape fields, insects appeared to visit flowers rather rarely and pollination limitation occurred in only one of three regions, which suggests that the crop has low pollinator-dependence in some instances. The earliness of flowering in relation to wild pollinator peak activity may limit improving insect pollination of winter oilseed rape even though insect pollination is higher where there was a rich bee community, especially solitary bees (Lasioglossum spp.) (Perrot et al., 2018) and where flower-rich habitats are adjacent to oilseed rape fields and levels of greening measures are high (Sutter et al., 2018). In regions with low pollination potential, growers may benefit from using crop varieties with lower pollinator-dependence or introduce honey bees for openpollinated cultivars, which may increase yields by up to $11 \%$ (Lindström et al., 2016).

The proportion and types of semi-natural habitat in the landscape can influence the levels of pollinators and thereby pollination (Martins et al., 2015), although the proportion of crops can also be more important (Pfister et al., 2017). To provide a representative sample of existing landscapes, these studies were conducted in areas that encompassed a range of landscape compositions. Further analyses to examine the role of landscape composition are planned.

Our findings indicate that pollination limitation in entomophilous crops is influenced by at least two factors besides the availability of pollinator visits. First, mechanisms of non-insect pollination can compensate for flower visitation by pollinators, as exemplified by the oilseed rape fields in Estonia and the United Kingdom. Second, plant traits can reduce the effectiveness of even high levels of pollinator activity, as exemplified by the sunflower fields in Italy. Taken together, our study suggests that strategies for reducing pollination limitation in crops require an integrated understanding of both pollinators and the plants that they pollinate. Such knowledge will help to better target ecological intensification efforts and other measures of integrated pollination management to minimize pollination limitation due to shortages in suitable insect pollinators.

\section{Conclusions}

Overall, our study supports two main conclusions: (1) pollination limitation existed at moderate although economically significant levels for some crops in Europe; and (2) the levels of pollination limitation in 
crops did not show a clear relation with levels of in-field insect activity, which suggests the importance of other factors such as the efficacy of the dominant pollinator species or level of autonomous self-pollination.

\section{Datasets}

Data used in this study is available at the Open Research Exeter archive, .https://doi.org/10.24378/exe.2463

\section{Declaration of Competing Interest}

The authors declare that they have no known competing financial interests or personal relationships that could have appeared to influence the work reported in this paper.

\section{Acknowledgements}

The QuESSA project was funded by the European Union's Seventh Framework Programme for research, technological development and demonstration under grant agreement No 311879. Our thanks to all the farmers who allowed access to their fields and to all of the researchers who assisted with the field studies.

\section{Appendix A. Supplementary data}

Supplementary material related to this article can be found, in the online version, at https://doi.org/10.1016/j.agee.2020.107002.

\section{References}

Bartual, A.M., Bocci, G., Marini, S., Moonen, A.C., 2018. Local and landscape factors affect sunflower pollination in a Mediterranean agroecosystem. PLoS One 13, e0203990.

Bell, S.A., Cresswell, J.E., 1998. The phenology of gender in homogamous flowers: temporal change in the residual sex function of flowers of Oil-seed Rape (Brassica napus). Funct. Ecol. 12, 298-306.

Blaauw, B.R., Isaacs, R., 2014. Flower plantings increase wild bee abundance and the pollination services provided to a pollination-dependent crop. J. Appl. Ecol. 51, 890-898.

Cresswell, J.E., 2008. Estimating the potential for bee-mediated gene flow in genetically modified crops. In: James, R., Pitts-Singer, T. (Eds.), Bee Pollination in Agricultural Eco-Systems. Oxford University Press, Oxford, UK.

Dainese, M., Martin, E.A., Aizen, M.A., Albrecht, M., Bartomeus, I., Bommarco, R., et al.,
2019. A global synthesis reveals biodiversity-mediated benefits for crop production. Sci. Adv. 5, eaax0121.

Garratt, M., Bishop, J., Degani, E., et al., 2018. Insect pollination as an agronomic input: strategies for oilseed rape production. J. Appl. Ecol. 55, 2834-2842.

Hayter, K., Cresswell, J., 2006. The influence of pollinator abundance on the dynamics and efficiency of pollination in arable Brassica napus: implications for landscape-scale gene dispersal. J. Appl. Ecol. 43, 1196-1202.

Hoyle, M., Hayter, K.E., Cresswell, J.E., 2007. Effect of pollinator abundance on selffertilization and gene flow: application to GM canola. Ecol. Appl. 17, 2123-2135.

Hudewenz, A., Pufal, G., Bögeholz, A.-L., Klein, A.-M., 2014. Cross-pollination benefits differ among oilseed rape varieties. J. Agric. Sci. 152, 770-778.

IPBES, 2016. The assessment report of the intergovernmental science-policy platform on biodiversity and ecosystem services on pollinators, pollination and food production. In: Potts, S.G., Imperatriz-Fonseca, V.L., Ngo, H.T. (Eds.), Secretariat of the Intergovernmental Science-Policy Platform on Biodiversity and Ecosystem Services, Bonn, Germany.

Klein, A.M., Vaissiere, B.E., Cane, J.H., Steffan-Dewenter, I., Cunningham, S.A., Kremen, C., Tscharntke, T., 2007. Importance of pollinators in changing landscapes for world crops. Proc. R. Soc. Lond. B Biol. 274, 303-313.

Knight, T.M., Steets, J.A., Ashman, T.-L., 2006. A quantitative synthesis of pollen supplementation experiments highlights the contribution of resource reallocation to estimates of pollen limitation. Am. J. Bot. 93, 271-277.

Lindström, S.A.M., Herbertsson, L., Rundlöf, M., Smith, H.G., Bommarco, R., 2016. Largescale pollination experiment demonstrates the importance of insect pollination in winter oilseed rape. Oecologia 180, 759-769.

Losey, J.E., Vaughan, M., 2006. The economic value of ecological services provided by insects. BioScience 56, 311-323.

Martins, K.T., Gonzalez, A., Lechowicz, M.J., 2015. Pollination services are mediated by bee functional diversity and landscape context. Agric. Ecosyst. Environ. 200, 12-20.

OECD, 2005. Consensus Document on the Biology of Helianthus annuusl. (Sunflower). Series on Harmonisation of Regulatory Oversight in Biotechnology No. 31. Environment Directorate. Organisation for Economic Co-operation and Development (OECD), Paris.

Perrot, T., Gaba, S., Roncoroni, M., Gautier, J.-L., Bretagnolle, V., 2018. Bees increase oilseed rape yield under real field conditions. Agric. Ecosyst. Environ. 266, 39-48.

Pfister, S.C., Eckerter, P.W., Schirmel, J., Cresswell, J.E., Entling, M.H., 2017. Sensitivity of commercial pumpkin yield to potential decline among different groups of pollinating bees. Roy. Soc. Open Sci. 4, 170102.

Pfister, S.C., Eckerter, P.W., Krebs, J., Cresswell, J.E., Schirmel, J., Entling, M.H., 2018. Dominance of cropland reduces the pollen deposition from bumble bees. Sci. Rep. 8 , 13873.

Potts, S.G., Imperatriz-Fonseca, V., Ngo, H.T., Aizen, M.A., Biesmeijer, J.C., Breeze, T.D., Dicks, L.V., Garibaldi, L.A., Hill, R., Settele, J., Vanbergen, A.J., 2016. Safeguarding pollinators and their values to human well-being. Nature 540, 220.

Quinet, M., Jacquemart, A.L., 2015. Difference between pollination and parthenocarpy in the' Conference' pear production. Acta Hortic. 1094, 359-366.

Sutter, L., Albrecht, M., Jeanneret, P., 2018. Landscape greening and local creation of wildflower strips and hedgerows promote multiple ecosystem services. J. Appl. Ecol. $55,612-620$.

Wolowski, M., Ashman, T.-L., Freitas, L., 2014. Meta-analysis of pollen limitation reveals the relevance of pollination generalization in the Atlantic forest of Brazil. PLoS One 9, e89498. 